\title{
Completion of the Irradiation of Silicon Carbide Cladding Tube Specimens in the High Flux Isotope Reactor
}

Alicia Raftery Christian Petrie Gregory Hirtz Yutai Katoh Kory Linton

May 2018 


\section{DOCUMENT AVAILABILITY}

Reports produced after January 1, 1996, are generally available free via US Department of Energy (DOE) SciTech Connect.

Website http://www.osti.gov/scitech/

Reports produced before January 1, 1996, may be purchased by members of the public from the following source:

National Technical Information Service

5285 Port Royal Road

Springfield, VA 22161

Telephone 703-605-6000 (1-800-553-6847)

TDD 703-487-4639

Fax 703-605-6900

E-mail info@ntis.gov

Website http://classic.ntis.gov/

Reports are available to DOE employees, DOE contractors, Energy Technology Data Exchange representatives, and International Nuclear Information System representatives from the following source:

Office of Scientific and Technical Information

PO Box 62

Oak Ridge, TN 37831

Telephone 865-576-8401

Fax 865-576-5728

E-mail reports@osti.gov

Website http://www.osti.gov/contact.html

This report was prepared as an account of work sponsored by an agency of the United States Government. Neither the United States Government nor any agency thereof, nor any of their employees, makes any warranty, express or implied, or assumes any legal liability or responsibility for the accuracy, completeness, or usefulness of any information, apparatus, product, or process disclosed, or represents that its use would not infringe privately owned rights. Reference herein to any specific commercial product, process, or service by trade name, trademark, manufacturer, or otherwise, does not necessarily constitute or imply its endorsement, recommendation, or favoring by the United States Government or any agency thereof. The views and opinions of authors expressed herein do not necessarily state or reflect those of the United States Government or any agency thereof. 
Fusion \& Materials for Nuclear Systems Division

Completion of the Irradiation of Silicon Carbide Cladding Tube Specimens in the High Flux Isotope Reactor

\author{
Alicia Raftery \\ Christian Petrie \\ Gregory Hirtz \\ Yutai Katoh \\ Kory Linton
}

Date Published: May 2018

NSUF Work Package \#: UF-18OR020710

Work Package Manager: Kory Linton

Milestone \#: M3UF-18OR0207101

\title{
Prepared by
}

OAK RIDGE NATIONAL LABORATORY

Oak Ridge, TN 37831-6283

managed by

UT-BATTELLE, LLC

for the

US DEPARTMENT OF ENERGY

under contract DE-AC05-00OR22725 



\section{CONTENTS}

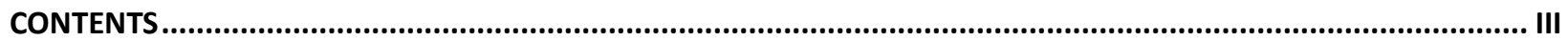

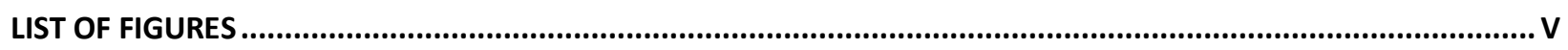

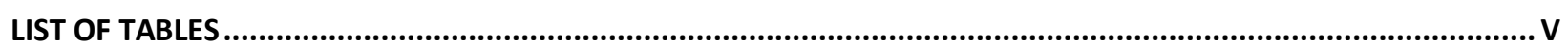

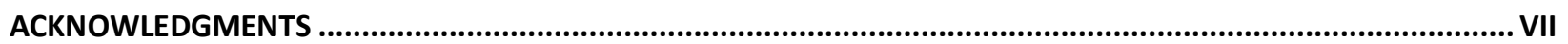

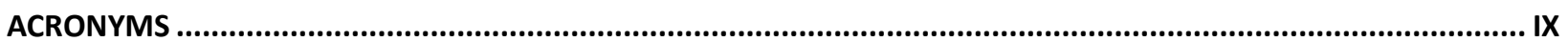

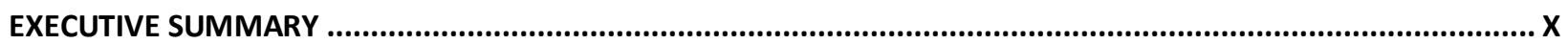

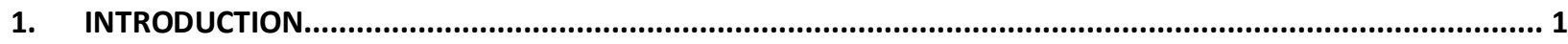

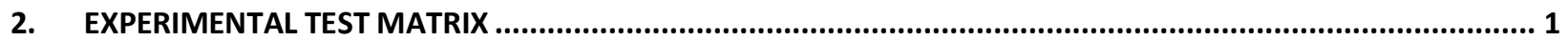

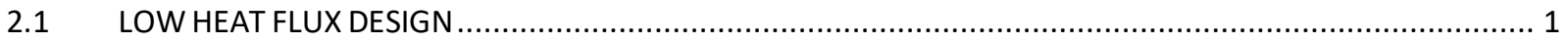

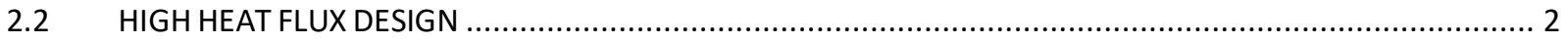

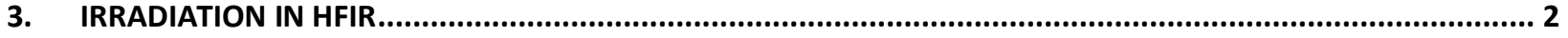

4. CONCLUSION

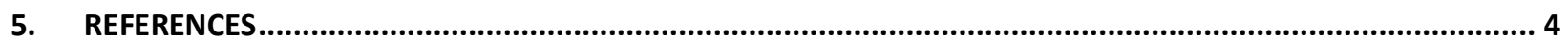

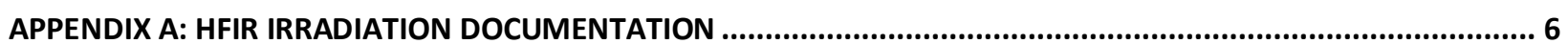





\section{LIST OF FIGURES}

Figure 1. Schematic of design for rabbit used to irradiate silicon carbide tube specimens under low heat flux conditions [6].

Figure 2. Schematic of rabbit design used to irradiate silicon carbide tube specimens under high heat flux conditions [6]....

Figure 3. Plot of accumulated dpa throughout the irradiation cycle for the monolithic CVD-L (rabbit SCL01) sample located in peripheral target position A1 axial location 5, which reached a total dose of approximately $2.67 \mathrm{dpa}$.....

Figure 4. Plot of accumulated dpa throughout the irradiation cycle for the monolithic CVD-E (rabbit ATFSC06) sample located in peripheral target position G4 axial location 4, which reached a total dose of approximately $2.61 \mathrm{dpa}$.

\section{LIST OF TABLES}

Table 1. Rabbit information and irradiation location for the SiC tube cladding specimens. 



\section{ACKNOWLEDGMENTS}

This research used resources at the High Flux Isotope Reactor, a DOE Office of Science User Facility operated by the Oak Ridge National Laboratory. Funding for this research was provided by the US Department of Energy, Office of Nuclear Energy Nuclear Science User Facility. This report was authored by UT-Battelle, LLC under Contract No. DE-AC05-00OR22725 with the US Department of Energy. 



\section{ACRONYMS}

HFIR High Flux Isotope Reactor

ORNL Oak Ridge National Laboratory

LWR Light-water reactors

PTP Peripheral target position

DPA Displacements per atom

LAMDA Low Activation Materials Development and Analysis

PIE Post-irradiation examination 


\section{EXECUTIVE SUMMARY}

This document outlines the irradiation of silicon carbide cladding tube specimens in the High Flux Isotope Reactor at Oak Ridge National Laboratory. The cladding tube specimens consisted of monolithic, composite, and coated $\mathrm{SiC}$ specimens in order to test the effect of these various materials on the overall cladding performance during irradiation. A total of 18 specimens were irradiated for one cycle, with 9 specimens irradiated at low heat flux conditions and 9 specimens at high heat flux conditions. The specimens were inserted in cycle 475 in September 2017 and reached an average irradiation dose of approximately $2.6 \mathrm{dpa}$. 



\section{INTRODUCTION}

Silicon carbide $(\mathrm{SiC})$ is being considered as an alternative to zircaloy cladding in light water reactors (LWRs) due to its potential for superior performance during accident scenarios. Identified SiC material properties that may improve cladding behavior during accidents include a high temperature strength, oxidation resistance, and stability under irradiation [1,2]. However, there are still a number of challenges regarding validation of $\mathrm{SiC}$ as a cladding for LWRs. For example, recent studies show that $\mathrm{SiC}$ has a high temperature dependence on swelling, which may create complicated stress states and microcracking in the material during irradiation [3]. In addition, poor hydrothermal corrosion of $\mathrm{SiC}$ in water could be detrimental for cladding performance during normal reactor operation [4]. Coated $\mathrm{SiC}$ specimens and $\mathrm{SiC}$ composites are currently under investigation due to the potential of the coatings to mitigate these issues [5].

This report briefly describes the experimental test matrix and summarizes the successful irradiation of 18 coated and composite SiC cladding tube specimens in the High Flux Isotope Reactor (HFIR). Half of the specimens were irradiated with high heat flux conditions and the other half at low heat flux irradiation conditions.

\section{EXPERIMENTAL TEST MATRIX}

The experiment consisted of two different rabbit designs in order to isolate the effect of irradiation damage in the absense of a temperature gradient in the material. The high heat flux design is used to simulate LWR reactor conditions while the low heat flux design is used to eliminate the temperature gradient across the cladding. Three low heat flux rabbits and three high heat flux rabbits were irradiated to a target temperature of approximately $300-350^{\circ} \mathrm{C}$. The irradiated specimens consisted of a collection of various $\mathrm{SiC}$ materials: monolithic, composite, and duplex coated samples.

\subsection{LOW HEAT FLUX DESIGN}

The low heat flux design contains three hollow $\mathrm{SiC}$ tube specimens backfilled with a helium-argon gas mixture, which maintains a minimal temperature gradient across the specimens. The three $\mathrm{SiC}$ specimens are separated by aluminum centering thimbles and a compression spring is used at the end to keep all of the samples held in place within the rabbit. Figure 1 shows a schematic of the low heat flux rabbit design. The monolithic $\mathrm{SiC}$ specimens act as the temperature monitor during the irradiation, removing the need for additional thermometry.

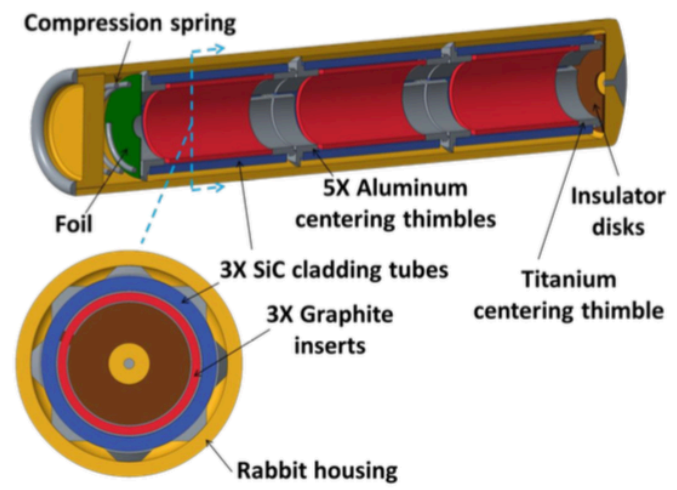

Figure 1. Schematic of design for rabbit used to irradiate silicon carbide tube specimens under low heat flux conditions [6]. 


\subsection{HIGH HEAT FLUX DESIGN}

The high heat flux design has a molybdenum heater located in the center of the samples. The heater drives the temperature gradient, simulating operating reactor cladding conditions. The outer surface of the sample is in contact with an aluminum sleeve surrounded by aluminum foil within the rabbit housing for adequate heat removal. The heat flux is approximately $0.66 \mathrm{MW} / \mathrm{m}^{2}$ at the outer surface of the cladding [7]. Figure 2 shows a schematic of the high heat flux design. A SiC temperature monitor was located inside of the molybdenum tube to verify the temperatures reached during irradiation.

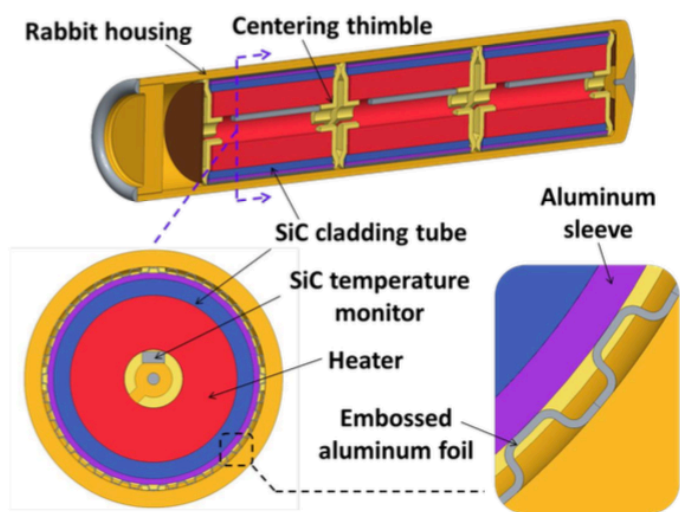

Figure 2. Schematic of rabbit design used to irradiate silicon carbide tube specimens under high heat flux conditions [6].

\section{IRRADIATION IN HFIR}

The 18 silicon carbide specimens were irradiated in HFIR for one cycle in September 2017. The specimens were put into peripheral target positions (PTP), with each specific rabbit location listed in Table 1. The target irradiation conditions included a fluence of $2.3 \times 10^{21}-2.4 \times 10^{21} \mathrm{n} / \mathrm{cm}^{2}$ and irradiation temperature of approximately $325^{\circ} \mathrm{C}$ at the surface of the specimen [6]. Additional documents regarding the insertion of the rabbits into HFIR are included in Appendix A.

\begin{tabular}{|c|c|c|c|c|}
\hline Heat Flux & Rabbit & Sample ID & Core Position & SiC Material Type \\
\hline Low & SCL01 & CVD-L & A1-5 & Monolithic \\
Low & SCL01 & SA3-1 & A1-5 & Inner Composite, Outer Monolithic \\
\hline Low & SCL01 & N1N3(1) & A1-5 & SiC/SiC Composite \\
\hline Low & SCL05 & CVD-Q & D1-5 & Monolithic \\
\hline Low & SCL05 & 6-RP-CR & D1-5 & Inner Monolithic, Outer Composite \\
\hline Low & SCL05 & 2-TM-CrN & D1-5 & SiC/SiC Composite \\
\hline Low & SCL06 & CVD-R & G7-4 & Monolithic \\
\hline Low & SCL06 & 3-RP-CrN & G7-4 & Inner Monolithic, Outer Composite \\
\hline Low & SCL06 & 7-TM-TiN & G7-4 & SiC/SiC Composite \\
\hline High & ATFSC06 & CVD-E & G4-4 & Monolithic SiC \\
\hline High & ATFSC06 & GA-TGI-C-1 & G4-4 & SiC/SiC Composite \\
\hline High & ATFSC06 & N1N3(8) & G4-4 & SiC/SiC Composite \\
\hline High & ATFSC07 & CVD-H & A1-4 & Monolithic SiC \\
\hline High & ATFSC07 & TYPE S-1 & A1-4 & Inner Composite, Outer Monolithic \\
\hline High & ATFSC07 & SA3-2 & A1-4 & Inner Composite, Outer Monolithic \\
\hline High & ATFSC09 & CVD-G & A4-4 & Monolithic SiC \\
\hline High & ATFSC09 & 1-TM-CrN & A4-4 & Inner Monolithic, Outer Composite \\
\hline High & ATFSC09 & 4-RP-CrN & A4-4 & SiC/SiC Composite \\
\hline
\end{tabular}

Table 1. Rabbit information and irradiation location for the $\mathrm{SiC}$ tube cladding specimens. 
The irradiation dose during the cycle, measured in displacements per atom (dpa), was calculated for two $\mathrm{SiC}$ monolithic specimens using an online tool developed by Joseph Burns at ORNL. This tool calculates the evolution of dose and fluence during the irradiation of specimens in HFIR based on the material type and location in the reactor (http://jburns33.pythonanywhere.com/). The results for the progression of dose during irradiation of the two specimens were calculated using threshold displacement energies of $40 \mathrm{eV}$ for silicon and $20 \mathrm{eV}$ for carbon [8]. The total calculated accumulated dose for specimen CVD-L in rabbit SCL01 was $2.67 \mathrm{dpa}$ (Figure 3) and the total accumulated dose for CVD-E specimen in ATFSC06 was $2.61 \mathrm{dpa}$ (Figure 4). The doses are slightly different due to the different axial locations.
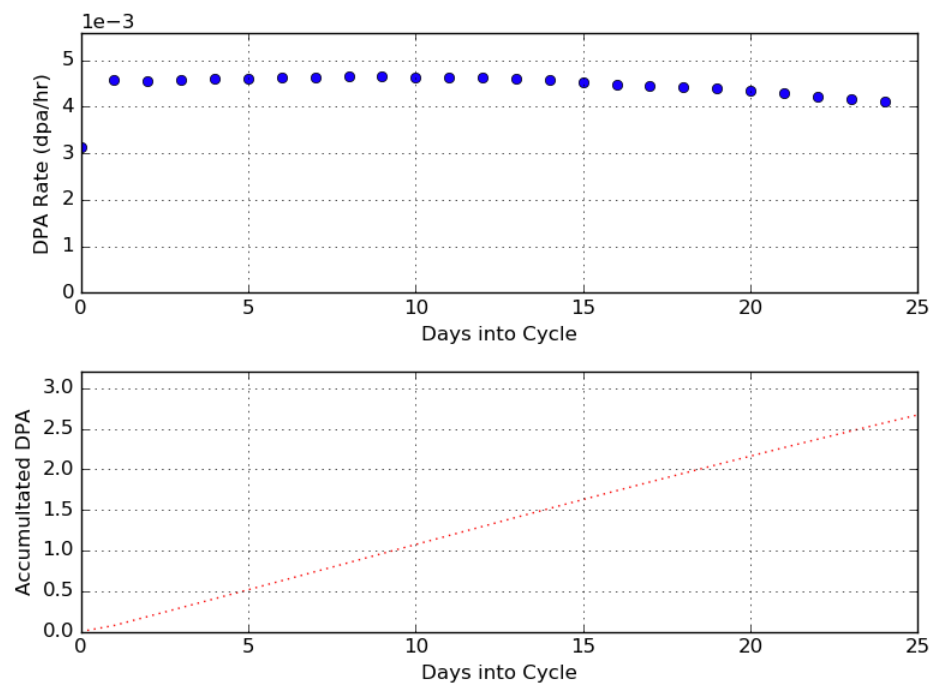

Figure 3. Plot of accumulated dpa throughout the irradiation cycle for the monolithic CVD-L (rabbit SCL01) sample located in peripheral target position A1 axial location 5, which reached a total dose of approximately 2.67 dpa.
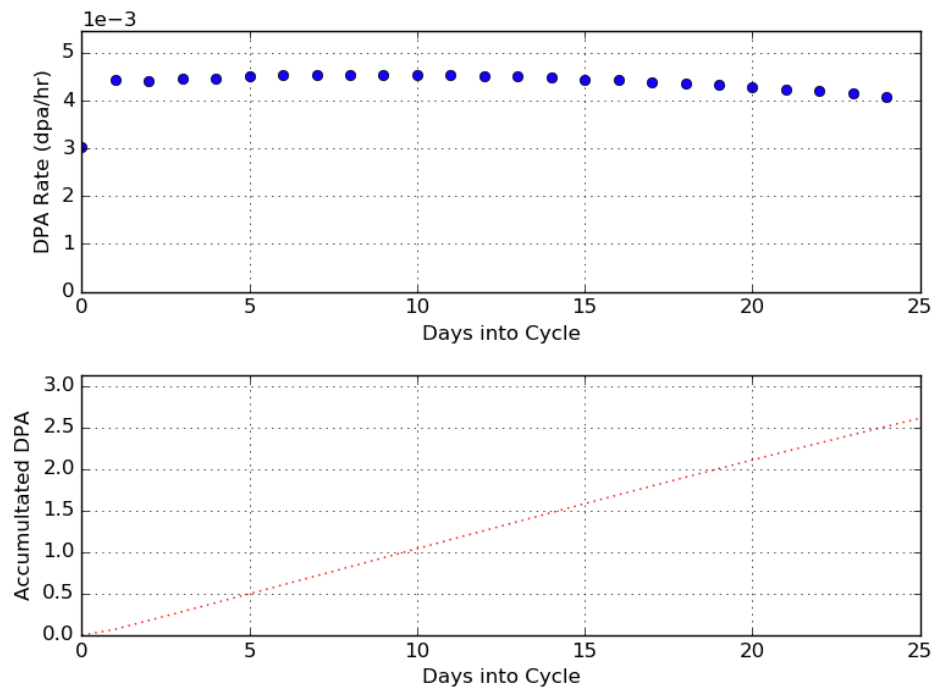

Figure 4. Plot of accumulated dpa throughout the irradiation cycle for the monolithic CVD-E (rabbit ATFSC06) sample located in peripheral target position G4 axial location 4, which reached a total dose of approximately $2.61 \mathrm{dpa}$. 


\section{CONCLUSION}

Six rabbit capsules successfully completed irradiation in HFIR after one cycle in September 2017. This concluded the design, build and irradiation of protyopical and model SiC-based ATF SiC cladding under a high and low radial heat flux scope under the Nuclear Science User Faciltiy (NSUF) Work Package: UF-18OR020710 for fiscal year 2018. The capsule shipment, hotcell disassembly, and Low Activation Materials Development and Analysis (LAMDA) laboratory post-irradiation examination (PIE) are underway. An initial report of the shipments and disassembly under Work Package UF-18OR020711 will follow this report in September 2018 and LAMDA PIE will continue until the end of fiscal year 2019.

\section{REFERENCES}

1. Cheng, T., et al, "SiC oxidation in steam environments at elevated temperature and pressure," Transactions of the American Nuclear Society, 106 (2012) p. 1233-1234.

2. Ozawa, K., et al, "Cavity swelling behavior in $\mathrm{SiC} / \mathrm{SiC}$ under charged particle irradiation," Fusion Science and Technology, 47 (2005) p. 871-875.

3. Singh, G., et al, "Evaluating the irradiation effects on the elastic properties of miniature monolithic SiC tubular specimens," Journal of Nuclear Materials, 499 (2018) p. 107-110.

4. Hirayama, H., et al, "Corrosion behavior of silicon carbide in $290 \mathrm{C}$ water," Journal of American Ceramic Society, 72 (1989) p. 2049-2053.

5. Terrani, K.A., "Accident tolerant fuel cladding development: promise, status, and challenges," Journal of Nuclear Materials, 501 (2018) p. 13-30.

6. Petrie, C. and T. Koyanagi, Assembly and delivery of rabbit capsules for irradiation of silicon carbide cladding tube specimens in the high flux isotope reactor. Oak Ridge National Laboratory: Oak Ridge, TN (2017).

7. Petrie, C.M., et al, "Experimental design and analysis for irradiation of $\mathrm{SiC} / \mathrm{SiC}$ composite tubes under a prototypic high heat flux," Journal of Nuclear Materials, 491 (2017) p. 94-104.

8. Zinkle, S.J., Kinoshita, C., "Defect production in ceramics," Journal of Nuclear Materials, 251 (1997) p. 200-217. 

APPENDIX A: HFIR IRRADIATION DOCUMENTATION

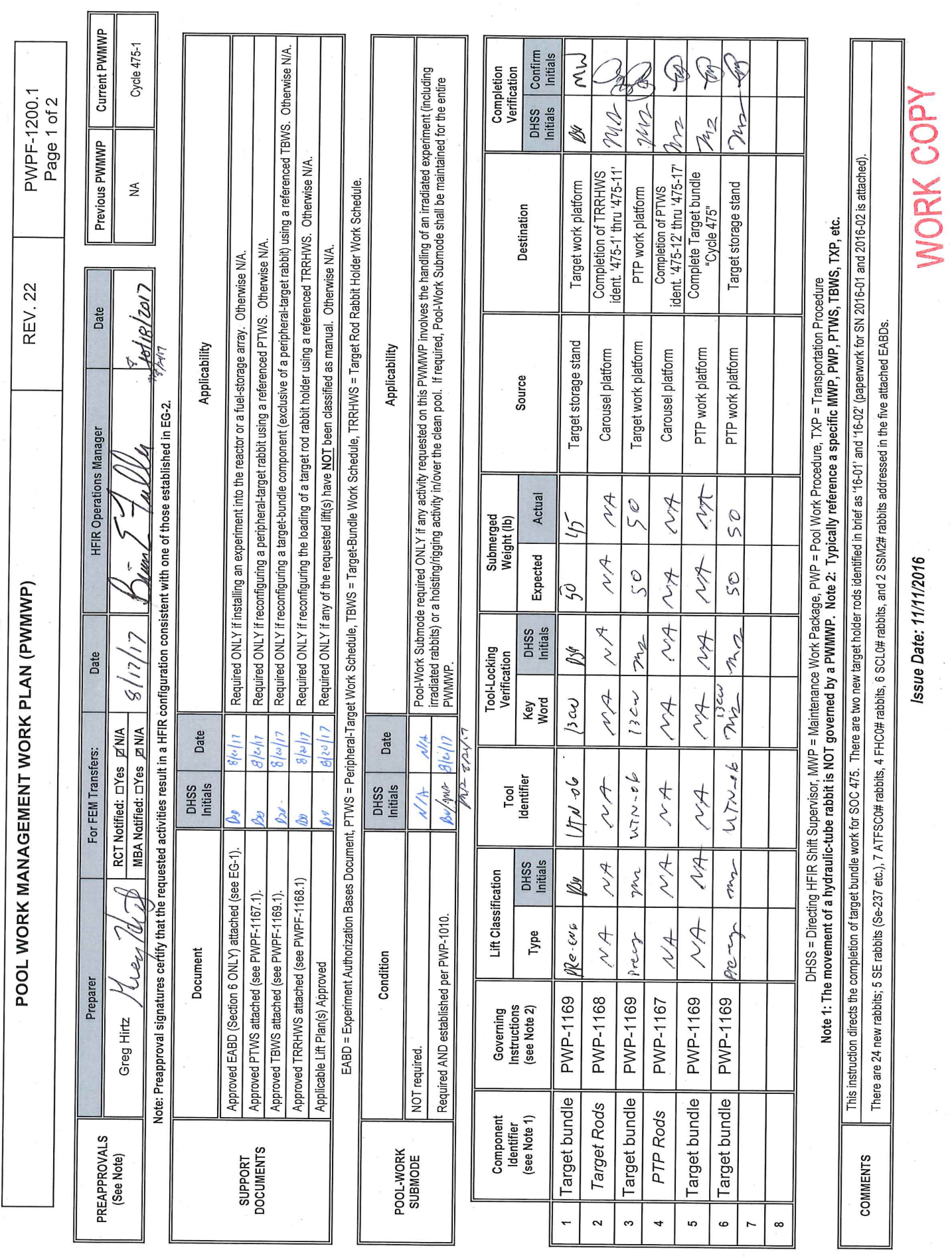




\begin{tabular}{|l|c|c|}
\hline TARGET BUNDLE WORK SCHEDULE & REV. 11 & $\begin{array}{c}\text { PWPF-1169.1 } \\
\text { Page } 1 \text { of } 2\end{array}$ \\
\hline
\end{tabular}

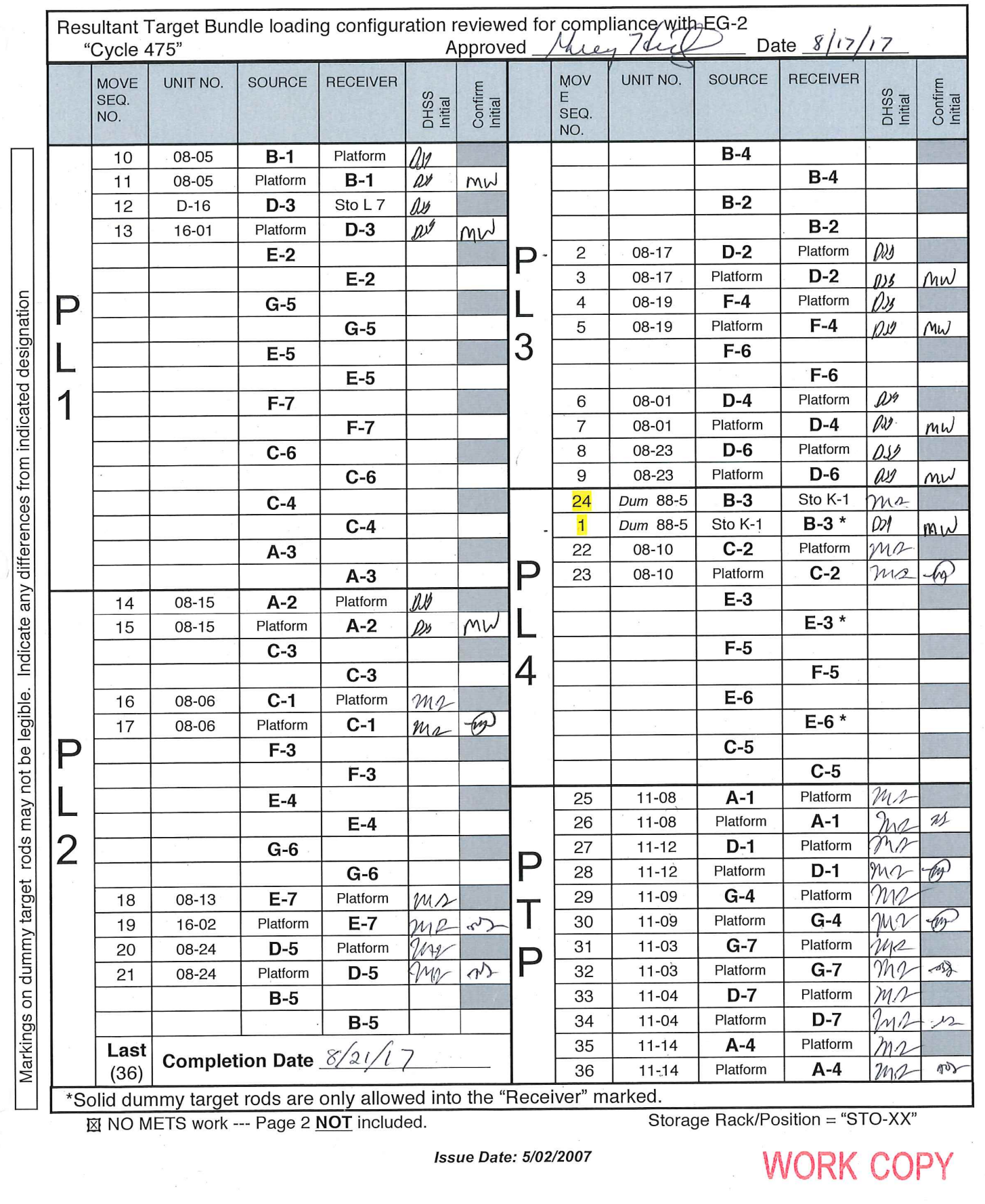




\begin{tabular}{|l|c|c|}
\hline PERIPHERAL TARGET WORK SCHEDULE (PTWS) & REV. 11 & $\begin{array}{c}\text { PWPF-1167.1 } \\
\text { Page } 1 \text { of } 1\end{array}$ \\
\hline
\end{tabular}

The changes to starting configuration and resulting ending configuration were reviewed and meet the limits below:

$\square$ Ending Rabbit Configuration is adequately cooled under $130 \%$ reactor overpower conditions.

Reference Calculation: C-HFIR-2001-026, C-HFIR-2003-040, C-HFIR-2004-060, C-HFIR-2015-019, C-HFIR-2016-041, C-HFIR-2017-003

$\square$ Ending Rabbit Configuration is adequately cooled under reactor transient conditions associated with LOOP

AND SBLOCA accidents. Reference Calculation: C-HFIR-2001-026 (C-HFIR-2017-002)

$\square$ Ending Rabbit Configuration is adequately cooled under a $50 \%$ reduced flow condition.

Reference Calculation: C-HFIR-2001-026 (C-HFIR-2017-002)

Prepared/Approved by:

Reviewed/Approved by:

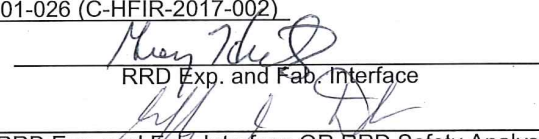

RRD Exp. and Fab. Interface OR RRD Safety Analyst

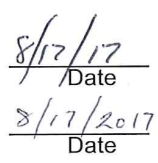

Starting Configuration for: 11-08

Identifier: $475-12$

\begin{tabular}{|l|c|c|c|c|c|c|c|}
\multicolumn{1}{c}{ End plug } & Pos 1 & Pos 2 & Pos 3 & Pos 4 & \multicolumn{1}{c}{ Pos 5 } & \multicolumn{2}{c}{ Pos 6 7} \\
\hline & $5-05-20$ & S-87 & S-72 & S-74 & FCAB06 & FCZ02 & \\
\hline
\end{tabular}

\begin{tabular}{|c|c|c|c|c|c|c|}
\hline Activity & Move \# & Unit No. (s) & FROM & TO & $\begin{array}{l}\text { DHSS } \\
\text { initial }\end{array}$ & $\begin{array}{l}\text { Confirm } \\
\text { initial }\end{array}$ \\
\hline Transfer & N/A & PTP__11-08_ & Target Bundle & PTP Unthreading Plate & $m \Omega$ & is \\
\hline Unload & N/A & Rabbits in PTP__11-08_ & $\begin{array}{l}\text { PTP Unthreading } \\
\text { Plate }\end{array}$ & Dump Tray & me & it \\
\hline \multirow[t]{7}{*}{ Store } & N/A & FCAB06 & Dump tray & Sto Basket 'E' & $m$ & 2 \\
\hline & N/A & S-74 & Dump tray & Sto Basket 'A' & $m_{2}$ & $M$ \\
\hline & N/A & & & & & \\
\hline & N/A & & & & & \\
\hline & N/A & & & & & \\
\hline & N/A & & & & & \\
\hline & N/A & & & & & \\
\hline & & & & & & \\
\hline Transfer & N/A & PTP-11-08 w/ end plug & $\begin{array}{l}\text { PTP Unthreading } \\
\text { Plate }\end{array}$ & Loading station & $M_{2}$ & $M$ \\
\hline \multirow[t]{7}{*}{ Load } & 1 & & & Position 7 & & \\
\hline & 2 & FCZO2 & Dump tray & Position 6 & $\ln 2$ & $\Lambda$ \\
\hline & 3 & SCL01 & Pool side & Position 5 & $\ln 2$ & 12 \\
\hline & 4 & ATFSC07 & Pool side & Position 4 & Mn & $M$ \\
\hline & 5 & S-72 & Dump tray & Position 3 & nn 2 & $\Lambda$ \\
\hline & 6 & S-87 & Dump tray & Position 2 & 912 & 2 \\
\hline & 7 & $5-05-20$ & Dump tray & Position 1 & $m \Omega$ & If \\
\hline Transfer & N/A & PTP- $\underline{11-08}$ w/end plug & Loading station & Target Bundle & $n n 2$ & \\
\hline
\end{tabular}

Ending Configuration for: $11-08$

\begin{tabular}{|c|c|c|c|c|c|c|c|}
\hline End plug & Pos 1 & Pos 2 & Pos 3 & Pos 4 & Pos 5 & Pos 6 & Pos 7 \\
\hline & $5-05-20$ & S-87 & S-72 & ATFSC07 & SCL01 & FCZ02 & \\
\hline
\end{tabular}

Comments on mechanical operation or appearance of the PTP rabbit holder: 
PERIPHERAL TARGET WORK SCHEDULE (PTWS)

REV. 11

PWPF-1167.1

Page 1 of 1

The changes to starting configuration and resulting ending configuration were reviewed and meet the limits below:

$\square$ Ending Rabbit Configuration is adequately cooled under $130 \%$ reactor overpower conditions.

Reference Calculation: C-HFIR-2001-026, C-2003-040, C-HFIR-2004-060, C-HFIR-2016-041

$\square$ Ending Rabbit Configuration is adequately cooled under reactor transient conditions associated with LOOP

AND SBLOCA accidents. Reference Calculation: C-HFIR-2001-026 (C-HFIR-2017-002)

$\square$ Ending Rabbit Configuration is adequately cooled under a $50 \%$ reduced flow condition. Reference Calculation: C-HFIR-2001-026 (C-HFIR-2017-002)

Prepared/Approved by: 1

(leyere

RRD Exp. and Fab. Thterface

Reviewed/Approved by:

RRD Exp. and Fab. Interface OR RRD Safety Analys

$$
\frac{8 / 12 / 57}{\frac{\text { Date }}{8 / 17 / 2017}}
$$

Starting Configuration for: 11-12

Identifier: $475-13$

\begin{tabular}{|c|c|c|c|c|c|c|}
\hline Activity & Move \# & Unit No. (s) & FROM & TO & $\begin{array}{l}\text { DHSS } \\
\text { initial }\end{array}$ & $\begin{array}{l}\text { Confirm } \\
\text { initial }\end{array}$ \\
\hline Transfer & N/A & PTP-11-12 & Target Bundle & PTP Unthreading Plate & 942 & $n$ \\
\hline Unload & N/A & Rabbits in PTP-11-12 & $\begin{array}{l}\text { PTP Unthreading } \\
\text { Plate }\end{array}$ & Dump Tray & nis & as \\
\hline \multirow[t]{8}{*}{ Store } & N/A & FCAB02 & Dump Tray & Sto Basket 'E' & nn & es \\
\hline & N/A & S-20 & Dump Tray & Sto Basket 'A' & onn & $\alpha$ \\
\hline & N/A & & & & & \\
\hline & N/A & & & & & \\
\hline & N/A & & & & & \\
\hline & N/A & & & & & \\
\hline & N/A & & & & & \\
\hline & & & & & & \\
\hline Transfer & N/A & PTP- $11-12$ w/ end plug & $\begin{array}{l}\text { PTP Unthreading } \\
\text { Plate }\end{array}$ & Loading station & $n=2$ & ss \\
\hline \multirow[t]{7}{*}{ Load } & 1 & & & Position 7 & & \\
\hline & 2 & S-53 & Dump Tray & Position 6 & 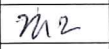 & us \\
\hline & 3 & SCL05 & Pool side & Position 5 & $n_{2}$ & is \\
\hline & 4 & SCL02 & Pool side & Position 4 & $m 2$ & 11 \\
\hline & 5 & S-56 & Dump Tray & Position 3 & $M / 2$ & 11 \\
\hline & 6 & S-25 & Dump Tray & Position 2 & $M \Omega$ & 21 \\
\hline & 7 & $5-05-23$ & Dump Tray & Position 1 & $m 2$ & Is \\
\hline Transfer & N/A & PTP- $11-12$ w/end plug & Loading station & Target Bundle & inn & \\
\hline
\end{tabular}

\begin{tabular}{|l|c|c|c|c|c|c|c|}
\multicolumn{1}{c}{ End plug } & Pos 1 & Pos 2 & Pos 3 & Pos 4 & Pos 5 & \multicolumn{2}{c}{ Pos 6} \\
\hline & $5-05-23$ & S-25 & S-56 & S-20 & S-53 & FCAB02 & \\
\hline
\end{tabular}

Ending Configuration for: $11-12$

\begin{tabular}{|c|c|c|c|c|c|c|c|} 
End plug & Pos 1 & Pos 2 & Pos 3 & Pos 4 & Pos 5 & \multicolumn{1}{c}{ Pos 7} \\
\hline & $5-05-23$ & S-25 & S-56 & SCL02 & SCL05 & S-53 & \\
\hline
\end{tabular}

Comments on mechanical operation or appearance of the PTP rabbit holder: 


\begin{tabular}{|l|l|l|}
\hline PERIPHERAL TARGET WORK SCHEDULE (PTWS) & REV. 11 & $\begin{array}{c}\text { PWPF-1167.1 } \\
\text { Page } 1 \text { of } 1\end{array}$ \\
\hline
\end{tabular}

The changes to starting configuration and resulting ending configuration were reviewed and meet the limits below:

Ending Rabbit Configuration is adequately cooled under $130 \%$ reactor overpower conditions.

Reference Calculation: C-HFIR-2001-026, C-HFIR-2015-019, C-HFIR-2016-041

Ending Rabbit Configuration is adequately cooled under reactor transient conditions associated with LOOP

AND SBLOCA accidents. Reference Calculation: C-HFIR-2001-026

$\square$ Ending Rabbit Configuration is adequately cooled under a $50 \%$ reduced flow condition. Reference Calculation: C-HFIR-2001-026

Prepared/Approved by:

Reviewed/Approved by:

Starting Configuration for: 11-09

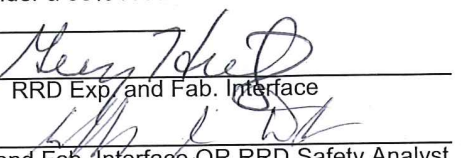

RRD Exp. and Faab. Interface OR RRD Safety Analyst

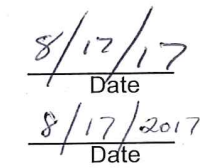

2

Identifier: $475-14$

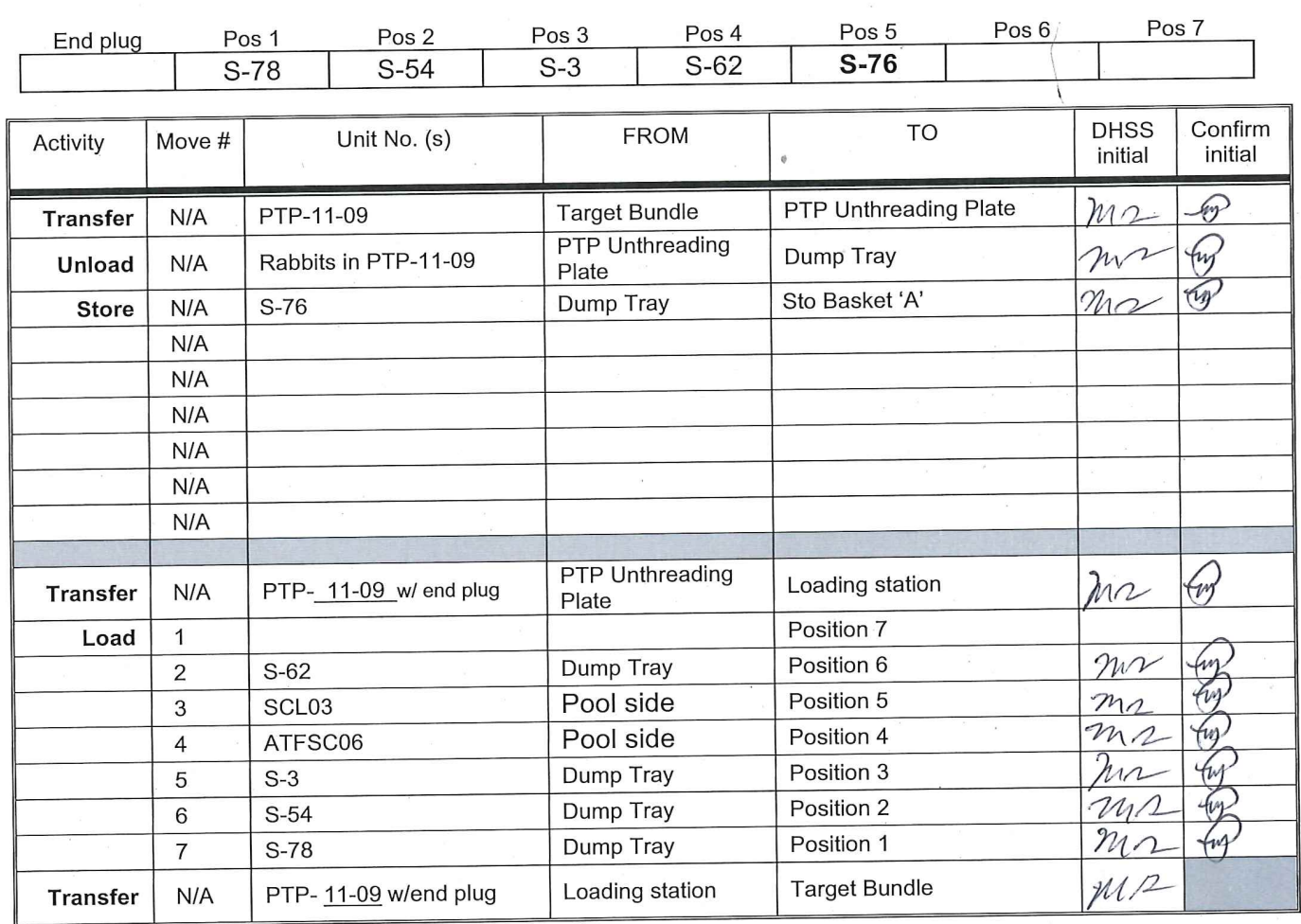

Ending Configuration for: $11-09$

\begin{tabular}{|l|l|l|l|l|l|l|l|}
\multicolumn{1}{|c}{ End plug } & Pos 1 & Pos 2 & Pos 3 & Pos 4 & Pos 5 & Pos 6 & Pos 7 \\
\hline & S-78 & S-54 & S-3 & ATFSC06 & SCL03 & S-62 & \\
\hline
\end{tabular}

Comments on mechanical operation or appearance of the PTP rabbit holder: 
PERIPHERAL TARGET WORK SCHEDULE (PTWS)

REV. 11

PWPF-1167.1

Page 1 of 1

The changes to starting configuration and resulting ending configuration were reviewed and meet the limits below:

$\square$ Ending Rabbit Configuration is adequately cooled under $130 \%$ reactor overpower conditions.

Reference Calculation:_C-HFIR-2001-026, C-HFIR-2008-045, C-HFIR-2016-041

$\square$ Ending Rabbit Configuration is adequately cooled under reactor transient conditions associated with LOOP AND SBLOCA accidents. Reference Calculation: C-HFIR-2001-026

$\square$ Ending Rabbit Configuration is adequately cooled under a $50 \%$ reduced flow condition.

Reference Calculation:

C-HFIR-2001-026

Prepared/Approved by:

Ler $/ 20$

RRD Exp. add Fab. Interface

Reviewed/Approved by:

RRD Exp. and Fat

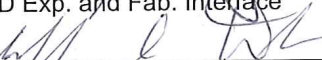

Fab. Interface OR RRD' Safety Analyst

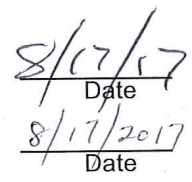

Starting Configuration for: $11-03$

Identifier: $475-15$

\begin{tabular}{|l|c|c|c|c|c|c|c|}
\multicolumn{1}{c}{ End plug } & Pos 1 & Pos 2 & Pos 3 & Pos 4 & Pos 5 & Pos 7 \\
\hline & S-1 & S-69 & S-9 & S-52 & FCAT07 & FCAT08 & \\
\hline
\end{tabular}

\begin{tabular}{|c|c|c|c|c|c|c|}
\hline Activity & Move \# & Unit No. (s) & FROM & TO & $\begin{array}{l}\text { DHSS } \\
\text { initial }\end{array}$ & $\begin{array}{l}\text { Confirm } \\
\text { initial }\end{array}$ \\
\hline Transfer & N/A & PTP__11-03_ & Target Bundle & PTP Unthreading Plate & M2 & $-(49)$ \\
\hline Unload & N/A & Rabbits in PTP__11-03_ & $\begin{array}{l}\text { PTP Unthreading } \\
\text { Plate }\end{array}$ & Dump Tray & $2 n 2$ & \\
\hline \multirow[t]{7}{*}{ Store } & N/A & S-52 & Dump Tray & Sto Basket 'A' & 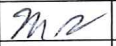 & -10 \\
\hline & N/A & & Dump Tray & & & \\
\hline & N/A & . & Dump Tray & & & \\
\hline & N/A & & Dump Tray & & & \\
\hline & N/A & & Dump Tray & & & \\
\hline & N/A & & Dump Tray & & & \\
\hline & N/A & & Dump Tray & & & \\
\hline & & & & & & \\
\hline Transfer & N/A & PTP-_11-03 w/ end plug & $\begin{array}{l}\text { PTP Unthreading } \\
\text { Plate }\end{array}$ & PTP Loading Station & $m_{2}$ & \\
\hline \multirow[t]{7}{*}{ Load } & 1 & & Dump tray & Position 7 & & \\
\hline & 2 & FCAT08 & Dump tray & Position 6 & nes & \\
\hline & 3 & FCAT07 & Dump tray & Position 5 & hipe & \\
\hline & 4 & SCL06 & Pool side & Position 4 & $\sqrt[2]{2}$ & \\
\hline & 5 & S-9 & Dump tray & Position 3 & $M 2$ & \\
\hline & 6 & S-69 & Dump tray & Position 2 & $m 2$ & \\
\hline & 7 & S-1 & Dump tray & Position 1 & $m / 2$ & - \\
\hline Transfer & N/A & PTP-11-03 w/end plug & Loading station & Target Bundle & $\mathrm{mn}$ & \\
\hline
\end{tabular}

Ending Configuration for: $11-03$

\begin{tabular}{|c|c|c|c|c|c|c|c|} 
End plug & Pos 1 & Pos 2 & Pos 3 & Pos 4 & Pos 5 & Pos 6 & Pos 7 \\
& S-1 & S-69 & S-9 & SCL06 & FCAT07 & FCAT08 & \\
\hline
\end{tabular}

Comments on mechanical operation or appearance of the PTP rabbit holder: 


\begin{tabular}{|l|l|l|}
\hline PERIPHERAL TARGET WORK SCHEDULE (PTWS) & REV. 11 & $\begin{array}{c}\text { PWPF-1167.1 } \\
\text { Page } 1 \text { of } 1\end{array}$ \\
\hline
\end{tabular}

The changes to starting configuration and resulting ending configuration were reviewed and meet the limits below:

$\square$ Ending Rabbit Configuration is adequately cooled under $130 \%$ reactor overpower conditions.

Reference Calculation: C-HFIR-2001-026, C-HFIR-2003-040, C-HFIR-2004-060, C-HFIR-2007-020, C-HFIR-2017-003

$\square$ Ending Rabbit Configuration is adequately cooled under reactor transient conditions associated with LOOP

AND SBLOCA accidents. Reference Calculation: C-HFIR-2001-026

$\square$ Ending Rabbit Configuration is adequately cooled under a $50 \%$ reduced flow condition.

Reference Calculation: C-HFIR-2001-026

Prepared/Approved by:

Reviewed/Approved by:

Starting Configuration for: 11-14

Lecerte

RRD Exp. ard Fab. Intertace

L 2 (I)

RRD Exp. and Fąb. Interface OR RRD Safety Analyst

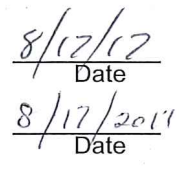

Identifier: $475-17$

\begin{tabular}{|l|c|c|c|c|c|c|c|}
\multicolumn{1}{|c}{ End plug } & Pos 1 & Pos 2 & Pos 3 & Pos 4 & Pos 5 & Pos 6 7 \\
\hline & S-17 & 5-05-24 & S-86 & FCAB04 & S-23 & FCZ05 & \\
\hline
\end{tabular}

\begin{tabular}{|c|c|c|c|c|c|c|}
\hline Activity & Move \# & Unit No. (s) & FROM & TO & $\begin{array}{l}\text { DHSS } \\
\text { initial }\end{array}$ & $\begin{array}{c}\text { Confirm } \\
\text { initial }\end{array}$ \\
\hline Transfer & N/A & PTP-11-14 & Target Bundle & PTP Unthreading Plate & $m \Omega$ & set \\
\hline Unload & N/A & Rabbits in PTP-11-14 & $\begin{array}{l}\text { PTP Unthreading } \\
\text { Plate }\end{array}$ & Dump Tray & $x=$ & th \\
\hline \multirow[t]{7}{*}{ Store } & $\mathrm{N} / \mathrm{A}$ & FCAB04 & Dump Tray & Sto basket 'E' & nn & ns \\
\hline & $\mathrm{N} / \mathrm{A}$ & S-23 & Dump Tray & Sto basket 'A' & $m=$ & 21 \\
\hline & N/A & & & & & \\
\hline & $\mathrm{N} / \mathrm{A}$ & & & & & \\
\hline & $\mathrm{N} / \mathrm{A}$ & & & & & \\
\hline & N/A & & & & & \\
\hline & N/A & & & & . & \\
\hline & & & & & & \\
\hline Transfer & N/A & PTP-11-14 w/ end plug & $\begin{array}{l}\text { PTP Unthreading } \\
\text { Plate }\end{array}$ & Loading station & $m n$ & It \\
\hline \multirow[t]{7}{*}{ Load } & 1 & & & Position 7 & & \\
\hline & 2 & FCZ05 & Dump Tray & Position 6 & nre & Is \\
\hline & 3 & SCL04 & Pool side & Position 5 & $n n 2$ & ns \\
\hline & 4 & ATFSC09 & Pool side & Position 4 & me & $m /$ \\
\hline & 5 & S-86 & Dump Tray & Position 3 & $2 m / 2$ & ast \\
\hline & 6 & $5-05-24$ & Dump Tray & Position 2 & nus & as \\
\hline & 7 & S-17 & Dump Tray & Position 1 & $n_{12}$ & a) \\
\hline Transfer & N/A & PTP- $11-14$ w/end plug & Loading station & Target Bundle & $m_{2}$ & \\
\hline
\end{tabular}

Ending Configuration for: $11-14$

\begin{tabular}{|l|l|l|l|l|l|l|l|}
\multicolumn{1}{c}{ End plug } & Pos 1 & Pos 2 & Pos 3 & Pos 4 & \multicolumn{1}{c}{ Pos 5} & Pos 6 & Pos 7 \\
\hline & S-17 & $5-05-24$ & S-86 & ATFSC09 & SCL04 & FCZ05 & \\
\hline
\end{tabular}

Comments on mechanical operation or appearance of the PTP rabbit holder: 